\title{
Different contents of fat in pork-based nuggets: a sensorial perspective
}

\author{
Diferentes teores de gordura em nuggets à base de carne suína: uma perspectiva sensorial
}

Diferentes contenidos de grasa en nuggets de carne de cerdo: una perspectiva sensorial

\author{
Alinton Augusto de Souza \\ ORCID: https://orcid.org/0000-0003-0544-3997 \\ Federal Institute of Northern Minas Gerais, Brazil \\ E-mail: alintonaugusto@gmail.com \\ Brena Lana Neres Barbosa \\ ORCID: https://orcid.org/0000-0001-7374-8077 \\ Federal Institute of Northern Minas Gerais, Brazil \\ E-mail: brenalana83@outlook.com.br \\ Julia Jordana Alves Rodrigues \\ ORCID: https://orcid.org/0000-0001-9903-7564 \\ Federal Institute of Northern Minas Gerais, Brazil \\ E-mail: julia.a.rodrigues@outlook.com.br \\ Lorena Mariara de Teixeira Silva \\ ORCID: https://orcid.org/0000-0002-1650-3468 \\ Federal Institute of Northern Minas Gerais, Brazil \\ E-mail: lo.mariaras@icloud.com \\ Nathalia Mendes Figueiredo \\ ORCID: https://orcid.org/0000-0003-1171-8475 \\ Federal Institute of Northern Minas Gerais, Brazil \\ E-mail: nathaliamfigueiredo@ufv.br \\ Clara Mariana Gonçalves Lima \\ ORCID: https://orcid.org/0000-0002-3150-9139 \\ Federal Institute of Northern Minas Gerais, Brazil \\ E-mail: claramarianalima@gmail.com \\ Flávia Michelon Dalla Nora \\ ORCID: https://orcid.org/0000-0001-7261-3787 \\ Federal University of Santa Maria, Brazil \\ E-mail: flavia1086@hotmail.com \\ Silvani Verruck \\ ORCID: https://orcid.org/0000-0003-0266-5885 \\ Federal University of Santa Catarina, Brazil \\ E-mail: silvani.verruck@ufsc.br \\ Thiago Moreira dos Santos \\ ORCID: https://orcid.org/0000-0001-8041-1149 \\ Federal Institute of Northern Minas Gerais, Brazil \\ E-mail: thiago.moreira@ifnmg.edu.br \\ Márcia Antunes dos Santos Rodrigues \\ ORCID: https://orcid.org/0000-0003-3459-2473 \\ Federal Institute of Northern Minas Gerais, Brazil \\ E-mail: marcia.rodrigues@ifnmg.edu.br \\ Daniela Caetano \\ ORCID: https://orcid.org/0000-0001-5397-7331 \\ Federal Institute of Northern Minas Gerais, Brazil \\ E-mail: daniela.caetano@ifnmg.edu.br
}

\begin{abstract}
With an increasingly busy lifestyle, consumers are looking for convenience, with products that are easy and quick to prepare. In this context, we highlight the restructured meat products breaded like nuggets. The study aimed to develop and evaluate nuggets made with pork by a sensory method. Three formulations with different concentrations of swine fat were prepared. The microbiological evaluation of the formulations was carried out, which did not present microbial contamination. The sensory acceptability assessment was conducted using a 9-point hedonic scale for the attributes softness, flavor, aroma, crispness, appearance, and overall impression of the product. Also, to assess the opinion of consumers regarding the product, a 5-point purchase intention test was applied. The results obtained show that the three samples obtained a score greater than or equal to 7 (I liked it regularly) by more than $90 \%$ of the judges. No score lower than 5 were attributed to the formulations, indicating low rejection of the products. Purchasing intentions were also high, with the percentage of judges indicating scores 4 and 5, corresponding to the terms "probably would buy" and "certainly buy" was $86.4,81.8$, and $84.5 \%$ for sample A, B, and C, respectively. The work
\end{abstract}


showed that pork-based nuggets with different fat contents obtained excellent acceptability and purchase intention, presenting themselves as a potential alternative for insertion in the consumer market.

Keywords: Meat product; Swine meat; Acceptability.

\section{Resumo}

Com um estilo de vida cada vez mais agitado, o consumidor busca por conveniência, com produtos de preparo fácil e rápido. Nesse contexto, destacam-se os produtos cárneos reestruturados empanados tipo nuggets. O objetivo do estudo foi desenvolver e avaliar sensorialmente nuggets elaborados com carne suína. Foram preparadas três formulações com diferentes concentrações de gordura suína. Realizou-se a avaliação microbiológica das formulações, as quais não apresentaram contaminação microbiana. A avaliação sensorial de aceitabilidade foi conduzida empregando uma escala hedônica de 9 pontos para os atributos maciez, sabor, aroma, crocância, aparência e impressão global do produto. Além disso, com o objetivo de avaliar a opinião dos consumidores frente ao produto, foi aplicado um teste de intenção de compra com escala de 5 pontos. Os resultados obtidos mostram que as três amostras obtiveram nota maior ou igual a 7 (gostei regularmente) por mais de $90 \%$ dos julgadores, sendo que nenhuma nota inferior a 5 foi atribuída às formulações, indicando baixa rejeição dos produtos. A intenção de compra também foi elevada, sendo que a porcentagem de julgadores que indicaram notas 4 e 5 , que correspondem respectivamente aos termos "provavelmente compraria" e "certamente compraria" foi de $86.4,81.8$ e $84.5 \%$ para a amostra A, B e C, respectivamente. O trabalho demonstrou que os nuggets à base de carne suína e com diferentes teores de gordura obtiveram ótima aceitabilidade e intenção de compra, apresentando-se como alternativa potencial de inserção no mercado consumidor.

Palavras-chave: Produto cárneo; Carne suína; Aceitabilidade.

\section{Resumen}

Con un estilo de vida cada vez más ajetreado, los consumidores buscan comodidad, con productos que sean fáciles y rápidos de preparar. En este contexto, destacamos los productos cárnicos reestructurados empanizados como pepitas. El objetivo del estudio fue desarrollar y evaluar sensorialmente los nuggets elaborados con carne de cerdo. Se prepararon tres formulaciones con diferentes concentraciones de grasa porcina. Se realizó la evaluación microbiológica de las formulaciones, las cuales no presentaron contaminación microbiana. La evaluación de aceptabilidad sensorial se realizó utilizando una escala hedónica de 9 puntos para los atributos suavidad, sabor, aroma, frescura, apariencia e impresión general del producto. Además, para evaluar la opinión de los consumidores sobre el producto, se aplicó una prueba de intención de compra de 5 puntos. Los resultados obtenidos muestran que las tres muestras obtuvieron una puntuación superior o igual a 7 (me gustaba habitualmente) por más del $90 \%$ de los jueces, sin que se atribuyera ninguna puntuación inferior a 5 a las formulaciones, lo que indica un bajo rechazo de los productos. Las intenciones de compra también fueron altas, con el porcentaje de jueces que indicaron puntajes 4 y 5 , correspondientes a los términos "probablemente compraría" y "ciertamente compraría" fue 86.4, 81.8 y $84.5 \%$ para las muestras A, B y C, respectivamente. El trabajo mostró que los nuggets de cerdo con diferentes contenidos grasos obtuvieron una excelente aceptabilidad e intención de compra, presentándose como una alternativa potencial de inserción en el mercado consumidor.

Palabras clave: Producto cárnico; Carne de cerdo; Aceptabilidad.

\section{Introduction}

With an increasingly agitated lifestyle and less time available to spend with food preparation, consumers are looking for convenience, products that are easy and quick to prepare. In this context, we highlight the restructured meat products like nuggets that are breaded and easy to prepare (Verma, Rajkumar, \& Kumar, 2019). According to the Technical Regulation on Identity and Quality, breaded products are industrialized meat products, obtained from meat of different animal species, added with ingredients, molded or not, and coated with an appropriate covering that characterizes it (Brasil, 2019).

Traditionally produced with chicken meat, nuggets are easy to prepare as well as to serve, and also have sensory characteristics well accepted by consumers, such as texture and flavor (Polizer, Pompeu, Hirano, Freire, \& Trindade, 2015). The restructured meat preparation is made by disintegrating the muscle by mechanical processes, followed by mixing the composition blocks, to later be formatted in specific portions, followed with three layers of coverage, called pre-batter, batter, and breading (Nunes, Trindade, Ortega, \& Castillo, 2006). The final breading process gives the products a longer shelf life when compared to raw meat, obtained mainly by the delay of oxidation and consequent appearance of rancidity. Also, the process of breading nuggets has the advantage of protecting food from dehydration during the freezing step (Dill, Silva, \& Luvielmo, 2009). 
According to the Brazilian Animal Protein Association (2020), swine shipments (considering all fresh and processed products) reached 87.5 thousand tons in November 2020, a number $31.7 \%$ higher than that achieved in 2019, with 66.4 thousand tons. And, for the first time in history, swine exports from Brazil exceeded two billion dollars, reaching US \$ 2.079 billion, 47.1\% more than the US \$1.413 billion made between January and November 2019.

Swine meat has $72 \%$ water, $20 \%$ protein, and $1 \%$ carbohydrate in its composition. It is a source of vitamin B1 (thiamine), which is extremely important in the metabolism of fats, carbohydrates and proteins, and other compounds of high nutritional value (Bragagnolo \& Rodriguez-Amaya, 2002; Hautrive, Marques, \& Kubota 2012). According to the Brazilian Animal Protein Association (2019), swine meat consumption in Brazil is 15.3 kilos per inhabitant. Brazilian slaughterhouses invest in quality control (Marzoque et al., 2020) as well as research bodies and educational institutions have joined forces about the technological development of swine products so that there is an increase in the consumption of this type of meat (Rodrigues et al., 2021; Silva et al., 2020; Yotsuyanagi et al., 2016).

Also in the context of the chemical composition of swine meat, it presents a high content of saturated fat. Thus, ways of processing this raw material into products with a lower concentration of fat is an objective to be achieved (Choi et al., 2013; Kim et al., 2020). This is because the ingestion of high amounts of fat can cause biochemical disturbances reflecting in some diseases, as dyslipidemias, hypertension, obesity, cardiovascular diseases (Choi et al., 2013). Therefore, the development of products with attractive sensory qualities and well accepted by consumers, combined with the reduction of fat concentration is a trend in the area of food technology (Kim et al., 2020).

In this sense, the objective of the study was to develop formulations of pork-based nuggets with different levels of pork fat, to carry out the microbiological and sensory evaluation of the product.

\section{Material and Methods}

\subsection{Raw Material and Processing}

The swine meat used in this work was provided by the Agribusiness sector of the Federal Institute of Northern Minas Gerais (IFNMG) Campus Salinas. After receiving the carcasses, boning and cuts of pork loin and chop were performed.

To prepare the nuggets, $15 \mathrm{~kg}$ of swine meat was passed through a $2 \mathrm{~cm}$ thick disc. Table 1 shows the treatments used in which it was realized a variation in the percentage of swine fat in each formulation. The formulations were defined according to preliminary tests (data not shown). 
Table 1. Nuggets formulations, $\mathrm{g}$ of each ingredient by $100 \mathrm{~g}$ of nuggets.

\begin{tabular}{lccc}
\hline \multicolumn{1}{c}{ Ingredients, \% } & \multicolumn{3}{c}{ Formulations } \\
& A & B & C \\
\hline Swine meat & 77.8 & 68.1 & 58.3 \\
Swine fat & 9.6 & 19.4 & 29.1 \\
Water & 7.8 & 7.8 & 7.8 \\
Salt & 1.5 & 1.5 & 1.5 \\
Garlic powder & 0.2 & 0.2 & 0.2 \\
Onion powder & 0.3 & 0.3 & 0.3 \\
Pepperoni pepper & 0.2 & 0.2 & 0.2 \\
Chimichurri & 0.2 & 0.2 & 0.2 \\
Monosodium glutamate & 0.2 & 0.2 & 0.2 \\
Emulsifier & 0.2 & 0.2 & 0.2 \\
Texturized soy pretein & 1.0 & 1.0 & 1.0 \\
Starch & 1.0 & 1.0 & 1.0 \\
\hline
\end{tabular}

Source: Authors.

After the homogenization of the ingredients, each batch was kept under refrigeration for 12 hours for the curing process. After this period, the nuggets were molded, followed by breading and subsequently the pre-frying step. This last step was performed by dipping the nuggets in soybean oil at a temperature of $180{ }^{\circ} \mathrm{C}$ for 60 seconds. Then, the samples were packed in properly identified polyethylene bags, and frozen in a freezer, at a temperature of $-18^{\circ} \mathrm{C}$.

\subsection{Microbiological analysis}

To evaluate the nuggets samples, microbiological analyses were performed in duplicate for total and thermotolerant coliforms. The analyses were conducted according to Normative Instruction (IN) ${ }^{\circ} 30$ de 26 de Junho de 2018 of Ministério da Agricultura Pecuária e Abastecimento (MAPA), which establishes official analytical methods for microbiological analysis to control products of animal origin and water.

\subsection{Sensory Analysis}

The sensory evaluation was approved by the Research Ethics Committee (CAAE: 12287019.3.0000.5146). The sensory evaluation of the nuggets took place in the Sensorial Analysis Laboratory, three days after processing with 110 untrained judges. The affective test was applied using a 9-point hedonic scale, in which grades 9 and 1 corresponded to the terms "I liked very much" and "I disliked very much", respectively. Through the acceptance test, the attributes of softness, flavor, crispness, appearance, aroma, and overall impression of the product were evaluated. Also, the purchase intention of the products was evaluated using a scale ranging from 5 to 1 , in which note 5 corresponded to the term "certainly would buy" and note 1 to the term "certainly would not buy".

For the sensory analysis, the preparation of the frozen products was carried out in a conventional oven (Safanelli, Brazil), using a temperature of $150{ }^{\circ} \mathrm{C}$ for 20 minutes. After preparing the samples, they were coded using 3 random digits and the three formulations of nuggets were placed on a white expanded polystyrene tray and then served to the tasters together with the evaluation form. 
The data obtained from the evaluation forms were evaluated using descriptive statistical analysis of the data and subjected to analysis of variance (ANOVA) and tests of comparison of Tukey's averages at the level of 5\% of significance using the software Microsoft Excel version 2013.

\section{Results and Discussion}

\subsection{Microbiological analysis}

The evaluation of the presence of total and thermotolerant coliforms in processed foods is important because it can indicate processing failures. According to the obtained results of microbiological analysis, it was possible to confirm that the preparation method of the processed meat products was suitable, taking into account that total and thermotolerant coliforms were absent in all samples.

\subsection{Sensory analysis}

The sensory analysis was applied to 110 judges, of which 62 were men and 38 were women. The median age of judges was between 19 to 21 years old, and more than $40 \%$ of the judges present age between 14 to 18 years. About the consumption frequency of swine meat, 62,31 and $5 \%$ of the judges informed, respectively, that they frequently, regularly, and occasionally consume this type of meat. Swine meat consumption is reported in $68 \%$ of judges because they appreciate the characteristics of the meat, while $19 \%$ consume it only because of the family habit.

The sensory analysis was done in relation to the attributes softness, aroma, flavor, crunchiness, appearance, and global impression using a hedonic scale composed of 9 points, in which point 1 corresponds to the term "really disliked", the point 5 corresponds to the term "I do not like or dislike" and the point 9 corresponds to the term "liked it very much". The results obtained from the sensory analysis are shown in Table 2.

Table 2. Scores mean attributed to the different formulations (A, B, and C) of pork-based nuggets*.

\begin{tabular}{lcccc}
\hline \multirow{2}{*}{ Attribute } & \multicolumn{3}{c}{ Formulations } & MSD* \\
& $\mathbf{A}$ & $\mathbf{B}$ & $\mathbf{C}$ & \\
\hline Softness & $7.65^{\mathrm{a}}$ & $8.17^{\mathrm{a}}$ & $8.12^{\mathrm{a}}$ & 0.69 \\
Aroma & $7.68^{\mathrm{a}}$ & $7.65^{\mathrm{a}}$ & $7.65^{\mathrm{a}}$ & 0.7 \\
Flavor & $7.91^{\mathrm{a}}$ & $8.05^{\mathrm{a}}$ & $8.13^{\mathrm{a}}$ & 0.36 \\
Crunchiness & $7.25^{\mathrm{a}}$ & $6.90^{\mathrm{a}}$ & $7.52^{\mathrm{a} . \mathrm{b}}$ & 0.47 \\
Appearance & $7.30^{\mathrm{a}}$ & $7.25^{\mathrm{a}}$ & $7.03^{\mathrm{a}}$ & 0.45 \\
Global impression & $7.79^{\mathrm{a}}$ & $7.94^{\mathrm{a}}$ & $7.96^{\mathrm{a}}$ & 0.33 \\
\hline
\end{tabular}

*Sensory analysis was made employing a hedonic scale with 9 points and a comparison of means by Tukey's test (MSD: Minimum Significant Differences) at a level of $5 \%$ of significance.

According to Table 2, it is possible to observe that all samples obtained a similar score, which remained between 6.90 and 8.13, corresponding to "liked it regularly" and "liked it much" terms, respectively. These results indicated that all samples were well accepted and no sample obtained a score lower than 6.9 for any attribute. According to Dutcosky (1996), the product must obtain an acceptability index of at least $70 \%$, that is, on a hedonic scale structured in 9 points, the grades must be higher than 6 to be considered sensorially accepted. 
Considering the scores assigned to all formulations, it is possible to observe that judges indicated acceptability for the 3 samples about all evaluated attributes. Worth pointing out that even with the change of fat concentration at the formulations, the assigned responses for all formulations were considered equal $(\mathrm{p}>0.05)$ for softness, aroma, flavor, and appearance attributes. For the crunchiness attribute, sample $\mathrm{C}$ (lower swine meat content and higher swine fat) received higher scores.

The crunchiness is the sensory property related to the sound that is produced and released during the chew (Luyten, Plijter, \& Van Vliet, 2004). Therefore, according to the obtained results in the sensory analysis conducted it was possible to observe that the sound produced during the chew of the formulation containing the higher fat concentration was considered more suitable by judges, making this formulation the one more accepted concerning this attribute.

The global impression, which takes into account all attributes as the flavor perceived by taste, the aroma and volatile compounds present in the samples, the sound produced during the chew, and the global appearance of the samples, it can be observed that all samples proved to be well accepted by the judges. According to scores attributed to different samples, it noticeable that on averages, all samples obtained scores next to 8, corresponding to the hedonic term "really like". In this sense, it can be possible to observe that the nuggets prepared with swine meat are a viable alternative to be incorporated into to daily diet.

Nunes et al. (2004) obtained similar results evaluating the global acceptance of nuggets prepared with chicken meat. More than $90 \%$ of the judges classified the product with the score 6 (like) and 7 (like it very much), which were maximum scores used in the study. These results have shown that the pork-based nuggets elaborated in this work have similar acceptance when compared with products that are traditionally on the market as chicken nuggets. On the other hand, Silva et al. (2020) evaluated the potential of coconut and tapioca flours as innovative gluten-free coatings in the elaboration of fish nuggets and the impact on sensory characteristics. Unlike this work, the treatment of fish nuggets coated with tapioca flour was sensorially rejected.

The buying intention is a sensory test applied to evaluate the will of judges to consume, acquire, or buy the evaluated product. In this sense, the buying intention test was conducted for all developed formulations using a scale with 5 points. For this test it was employed a 5 point scale, in which the score attributed by judges to formulations A, B and C were 4.24, 4.20, and 4.29, respectively, showing a good acceptance of all formulations by judges. Statistically, the buying intention was equal for all formulations. Terms of buying rejection were attributed by 0.9 and 1.8 of judges for $\mathrm{A}$ and $\mathrm{C}$ formulations, respectively. Sample B had no response to buying rejection (scores 1 and 2). Also, it is important to highlight that 86.4, 81.8 and 84.5\% of judges indicated terms 4 and 5 for samples A, B, and C, respectively, showing a high buying intention of these products. Thus, is possible to verify that the buying intention of these products, if they were available in commercial establishments, could be considered high.

\section{Conclusion}

According to the data presented in this work, all formulations of nuggets with different proportions of swine meat and fat were sensory well accept by judges. Through an acceptability test employing a 9-point hedonic scale was possible to verify that all samples present the average of results above 6.9, indicating good acceptance. About evaluated attributes as softness, aroma, flavor, appearance, and global impression, all samples were considered with the same acceptability, except for the crunchiness attribute, which the sample $\mathrm{C}$ was more acceptable than the other samples. Also, it was observed an extremely positive response to buying intention, taking into account that more than $80 \%$ of judges said they would buy the products if they were available in commerce. 
In this sense, it can be concluded that the use of swine meat for the production of nuggets is a viable alternative regardless of the fat content used. The nuggets with swine meat represent the opportunity to create a product with high nutritional value, low production cost, and added value.

\section{References}

Associação Brasileira de Proteína Animal. (2020). Exportações de aves e de suínos seguem em alta em 2020. http://abpa-br.org/exportacoes-jan-nov-2020/.

Associação Brasileira de Proteína Animal. (2019). Estatística do Setor. Gráficos dos Setores. https://abpa-br.org/mercados/page/2/.

Bragagnolo, N., \& Rodriguez-Amaya, D. B. (2002). Simultaneous determination of total lipid, cholesterol and fatty acids in meat and backfat of suckling and adult pigs. Food Chemistry, 79(2), 255-260.

Choi, Y-S., Park, K-S., Kin, H-W., Hwang, K-E., Song, D-H., Choi, M-S., Lee, S-Y., Paik, H- D., \& Kim, C- J. (2013). Quality characteristics of reduced-fat frankfurters with pork fat replaced by sunflower seed oils and dietary fiber extracted from makgeolli lees. Meat Science, 93(3), 652-658.

Dill, D. D., Silva, A. P., \& Luvielmo, M. M. (2009). Breaded processing: covering system. Technological Studies, 5(1), 33-49.

Dutcosky, S. D. (1996). Analise sensorial de alimentos. Curitiba: Universitária Champagnat.

Hautrive, T. P., Marques, A. C., \& Kubota, E. H. (2012). Avaliação da composição centesimal colesterol e perfil de ácidos graxos de cortes cárneos comerciais de avestruz, suíno, bovino e frango. Alimentos e Nutrição Araraquara, 23(2), 327-334.

Kim, T-K., Yong, H-I., Jung, S., Kim, Y-B., Choi, Y-S. (2020). Effects of replacing pork fat with grape seed oil and gelatine/alginate for meat emulsions. Meat Science, 163, 108079.

Luyten, H., J. Plijter, J. J, \& Van Vliet, T. (2004). Crispy/crunchy crusts of cellular solid foods: a literature review with discussion. Journal of texture studies, 35(5), 445-492.

Marzoque, H. J., Lima, C. M. G., Pagnossa, J. P., da Cunha, R. F., Silva, D. R. G., de Souza Ramos, A. L., \& Ramos, E. M. (2020). Evaluation of pH in swine carcasses regarding on the trasport distance of the animals: a case study. Research, Society and Development, 9(10), e6379108893.

Nunes, T. P., Trindade, M. A., Ortega, E. M. M., \& Castillo, C. J. C. (2006). Aceitação sensorial de reestruturados empanados elaborados com filé de peito de galinhas matrizes de corte e poedeiras comerciais. Food Science and Technology, 26(4), 841-846.

Polizer, Y. J., Pompeu, D., Hirano, M. H., Freire, M. T. D. A., \& Trindade, M. A. (2015). Development and evaluation of chicken nuggets with partial replacement of meat and fat by pea fibre. Brazilian Journal of Food Technology, 18(1), 62-69.

Rodrigues, I., Baldini, A., Pires, M., Barros, J. C., Fregonesi, R., de Lima, C. G., \& Trindade, M. A. (2021). Gamma ray irradiation: A new strategy to increase the shelf life of salt-reduced hot dog wieners. LWT, 135, 110265 .

Silva, J. S., Voss, M., de Menezes, C. R., Barin, J. S., Wagner, R., Campagnol, P. C. B., \& Cichoski, A. J. (2020). Is it possible to reduce the cooking time of mortadellas using ultrasound without affecting their oxidative and microbiological quality? Meat Science, $159,107947$.

Silva, M. C. A., Leite, J. S. A. F., Barreto, B. G., dos Anjos Neves, M. V., Silva, A. S., de Viveiros, K. M., ... \& Cavalheiro, C. P. (2020). The impact of innovative gluten-free coatings on the physicochemical, microbiological, and sensory characteristics of fish nuggets. $L W T, 110409$.

Verma, A. K., Rajkumar, V., \& Kumar, S. (2019). Effect of amaranth and quinoa seed flour on rheological and physicochemical properties of goat meat nuggets. Journal of food Science and Technology, 56(11), 5027-5035.

Yotsuyanagi, S. E., Contreras-Castillo, C. J., Haguiwara, M. M., Cipolli, K. M., Lemos, A. L., Morgano, M. A., \& Yamada, E. A. (2016). Technological, sensory and microbiological impacts of sodium reduction in frankfurters. Meat Science, 115, 50-59. 